Dr A.L. Combrink

Department of English

\title{
COMEDY IN THE SEVENTIES: A STUDY OF CERTAIN PLAYS BY HAROLD PINTER
}

\author{
Summary of doctoral thesis, completed \\ in 1979. Prof. J.A. Venter was \\ the supervisor.
}

Harold Pinter emerges from a survey of critical responses to his work as being at once the most praised and the most reviled of contemporary British playwrights. The present study is an attempt to shed some light on some of the problems confronting the reader of his works through approaching his plays as exemplars of the contemporary comic vision.

Chapter I contains a survey of criticism on Pinter. Criticism of his work has to some extent crystallized into certain trends or "schools". What emerges from a survey of twenty years' intensive critical activity is the fact that critical response to his work is as ambiguous and unsettled as ever. This is part of the motivation for the present study.

In dealing with criticism of his work, then, the following broad categories may be isolated.

Positive judgment has almost consistently centred on his undeniably effective manipulation of language. He is generally conceded to be a master craftsman of dramatic language with an acutely attuned ear for the nuances of speech.

Strong negative criticism has centred on his being wilfully and arbitrarily obscure. This characteristic can also be interpreted as ambiguity or complexity. A number of critics have sought to deal with the bafflingly ambiguous nature of the plays by resorting to myth and ritual as aids to understanding. There has also been some concern with the significance of Pinter's Jewish descent.

Far from regarding Pinter as esoteric and complex, some critics have maintained that his work is purely realistic, even naturalistic. This realism, however, 
is of a particular type which induces a sense of dislocation in the audience, and which has also induced a number of critics to regard Pinter as an exponent of the Absurd school.

A certain sense of reservation has been noted regarding the lack of moral vision in his work (particularly as regards The homecoming).

A promising area of critical concern has been the concern with Pinter's comic vision. It was illustrated that while many critics have indicated areas of comic appeal in his work, no single and exhaustive study of Pinter's comic vision has yet been undertaken. The aims formulated at the end of this chapter then are:

The formulation of a contemporary theory of comedy, inductively developed: and the application of this definition to

(a) Pinter's six full-length plays; and

(b) the two short television plays (The collection and The lover).

Chapter 2 deals with the justification for dealing seriously with generic distinctions. It is suggested that the playwright reveals his vision of life and the world most clearly in imbuing it with a sense of either tragedy or comedy. The study of genre is thus an important aid, a way into the play.

In spite of newer terms bcing invented, it is decided to adhere to the term comedy, without resorting to any qualifying adjectives.

Comedy is to be regarded as a mirror of the times, thus a new definition is needed for each new age: the permanent ways of comedy remain, while the variable superstructure is adapted to the changing needs of the times.

Chapter 3 contains a detailed examination and evaluation of comic theory. The difficulties facing the theorist of comedy are analysed and the field of investigation narrowed down to comic drama.

Some attention is paid to the fac that huther licoly ana comic theory have tended to be confused. I aughter theory (as it incorporates vicws on catharsis also) is carcfully evaluated and the "invasion" of laughter theory into comic theory disposed of with the perspective that laughter could be regarded as an inessential adjunct of comedy. Catharsis is accorded a carefully limited 
validity.

Comedy is discussed under varıous headings. In the critical consideration of comic theory a certain progression can be observed: the discussion starts with a consideration of comedy and society (as this aspect of comedy is generally considered to be the most inviolate of the permanent ways of comedy) and progresses ultimately to a consideration of comedy and cosmic homelessness; comedy and the despair of contemporary man (this aspect being the most recent addition to the variable superstructure). In between, other aspects are considered and evaluated, such as incongruity intellectual concerns and objectivity, the aspects of criticism or reduction, satire, compassion, limitation and imperfection, insight and maturity as well as acceptance, myth, redemption and the metaphysics of comedy.

A brief discussion of the relationships of comedy follows: farce is now generally regarded as a device of comedy rather than as a mode in itself, and tragedy is seen to have been temporarily eclipsed in a world devoid of faith in a metaphysical entity.

Following on this survey, a tentative notion of comedy could be formulated to act as a guideline in dealing with the works of a number of contemporary authors. These authors are Tom Stoppard, Joe Orton, Simon Gray, Peter Nichols and Trevor Griffiths.

A discussion of representative works by these playwrights yields the impression that while many of the permanent ways of comedy have remained (such as its social character, its vision of the disparateness of the world, its insistence on game and play, on the primacy of language, the importance of compassion, revelation, awareness of limitation) there has been an important movement in the direction of a totally bleak and non-redemptive characteristic in this drama. The typical comic hero in the contemporary situation is more isolated and at the end of the play is frozen in a characteristically catatonic stance.

The themes that emerge most persuasively are those of the contingent nature of truth and the paralysing influence of the part on the present.

The inhibitory effect of the past on the present has had a profound influence on the time-context of comedy, for the time-scheme has now persuasively become past-present instead of the traditional one of present-future. As a 
concomitant of this change there has been a movement towards a lack of hope and redemption in the place of the traditional hopeful pattern symbolized by the redemptive ending.

In the framework of contemporary literature one could then assert that the comic vision has become a means of coping with despair, of asserting man's residual dignity in the face of blankly hostile and often incomprehensible assaults on his sensibility. The black jokes and the savage humour often serve as a weapon against the invasions of emptiness, the awareness of cosmic homelessness, so that contemporary comedy has become a means of coping with the "whole experience", the flux and evancscene constituting modern life.

It is thus feasible to suggest that much of what has been called Theatre of the Absurd could equally well come under the umbrella of the contemporary vision of comedy.

This definition of comedy is developed for the purpose of finding a way into the plays of Harold Pinter.

In the course of a study of Pinter's comic vision it emerges that there is a clear developmental pattern. From the earliest comedies of menace his work has changed very markedly into comedies of manners, so that the last play, Betrayal, is a pure example of the manners tradition in English drama.

The birthday party is a comedy of menace: in a world peopled by pathetically inadequate characters two menacing figures intrude. The characters in the play constantly try (if pathetically and incffectually) to adapt to the social situation. Stanley emerges as a victim of a faceless and nameless force, and forces the spectator into an uneasy awareness of kinship with him, sharing his obscure sense of guilt and anxiety. Ilis limitations and imperfections.are mercilessly revealed so that he stands, ultimately, battered into submission, in the characteristic stance of catatonic over-acceptance. The play is both funny and frightening, the violence obstrusive.

The caretaker can still be regarded as a comedy of menace, but there is a real development in the sense that an awareness of mutual need has come into play. The play also hinges, as does the previous one, on an agonized quest for identity in a world that seems hostile and indifferent. The characters are shown up most revealingly in their ef forts to come to grips adequately with a mechanical facelessness. This striving is often accompanied by eruptions 
of violence, and farcical action has come, in this play, to be a paradigm for action in the pathetic need for assertion of the self. The quality of menace in this play has come to centre in a need for more fulfilling personal relationships. The characters in the play are still human derelicts, caught in a seemingly hostile environment and seemingly inarticulate but their attitude and stance at the end of the play are not materially different from those of the heroes of the later, more sophisticated plays.

The collection and The lover, alt hough relatively short plays, are important in the development of Pinter's comic vision because they involve more affluent and sophisticated characters, more elegant dramatic language and an overt shift to more explicitly sexual relationships all of which constitute features of the later plays, being a concomitant of the shift from menace to manners.

From this point onwards (and, incidentally, from this point onwards a strong similarity between Pinter and Coward has been noted), it becomes feasible to regard the consciously elegant language and the meticulously structured social games as efforts to structure reality, to create a sense of fixedness in a world in which there is a nauseating awareness of flux.

The homecoming, existing as it does to some extent in a moral vacuum, occupies a position of ambivalence - at the far end of the comic spectrum. The characters in the play might, charitably, be regarded as desperate more than evil, but even so the lack of a moral structure upsets the final balance.

The play is, on the one hand, a strong development in the direction of the comedy of manners. On the other hand, there is an appallingly vicious incidence of violence. The parallel development of violence and manners seems to occasion a curious quality of stasis, which is perhaps responsible for the abrupt plunge the play takes into unrelieved darkness. The obtrusive violence underscores the lack of love and caring, vividly highlighting the lack of redemption so painfully apparent in contemporary drama.

In Old times, regarded by some as the most sustained example of mannered comedy so far, there is a much stronger awareness of the inhibitory nature of the past, with the concomitant themes of the contingent and relative nature of the truth as revealed in recollection. The title of the play strikingly reveals the only valid time-scheme of contemporary comedy, for whereas the traditional time-scheme has been present future, it has become oppressively clear 
that the time-scheme of contemporary comedy can be no other than pastpresent, with the present heavily compromised by the detritus of the past.

In this play recollection is the central action, and the conflicting nature of recollections of the past by various characters would seem to account for the treacherous surface that the characters have to traverse. It is notable that humour seems to be the only means by which survival can be negotiated in this dangerously slippery environment. The games played in deadly carnest by the characters are more elaborate, more superficially entertaining, more fundamentally destructive, more elegant because of the greater measure of linguistic dexterity and adeptness. The games constitute an ever more important part of the action in direct proportion to the elimination of overt violence. Under the curiously static quality of the play lurk the familiar demons plaguing twentieth-century man in the shape of a defective awareness of identity, of anxiety, of unfulfilled dreams, of hopelessness, of a crying need, unlikely in the present scheme of things to be fulfilled in any meaningful way.

No man's land contains in a highly individualized and imaginative fashion the exploration of the themes of the quest for identity, the awareness of nced, the matter of friendship and the nature of time (together with the effect of the past, in varied recollected form, on the present). There is also a stronger and more insistent awareness of a nostalgia for a settled past.

The character types are more typical of the more mannered style of comedy, as is the world in which the characters move. This play also contains a very marked allusive structure - the elegant language constitutes a sophisticated verbal game which once again becomes a paradigm for existence. It is important that one of the implications of the move towards manners is that overt violence and aggression (so prevalent in the comedic's of menace) are gradually contained more and more effectively within a fixed social framework constituted of careful manoeuvring and games. The menace, however, is no less terrifying for being known, still inculcating in the ludicrously stripped characters the dread and anxiety indissolubly linked to men devoid of hope and so impervious to redemption and reconciliation.

This is most noticeable in Betrayal, I'inter's most recent play. This play is cast totally in the manners mould, with the merace seemingly completely submerged to emerge more subtly but no less terrifyingly from the social environment and from the games played with such meticulous observance of the rules. The pattern of need is most conspicuous in this play, with the al- 
most unbearably ironic concomitant of betrayal at every level and in every nuance. The compromising nature of the past with its inhibitory effect on the present is explored in particularly imaginative fashion through the dramatic structure. The sophisticated texture of the play, covering as it does the painful uncertainties, anxieties and fears of the polished and articulate characters, adds to the impact of the play. The play is is very much an imaginative twentieth-century recasting of a Restoration play with the profoundly significant difference that the quality of redemption has disappeared, leaving the characters to face the world w'ith an over-accepting attitude that hints forlornly at a fortitude born of hopelessness and lostness.

This study has thus resolved itself ir a threefold manner. What has been achieved is

(a) a contemporary definition of comedy, tailored to the needs of contemporary (British) comedy;

(b) an interpretation of Harold Pinters' major plays through an analysis of his comic vision; and

(c) the establishment of a developmental pattern, from menace to manners, in the plays of Harold Pinter. 